\title{
ADDITIONAL RESULTS OF COLLECTING INSECTS IN KANSAS AND COLORADO.
}

By E. S. Tucker, Bureau of Entomology. United States Department of Agriculture, Washington, D. C.

THE classification of insects in all orders requires a wide diver.

sification of study, which, beyond a limited extent, cannot be perfected by any one person, even under the most favorable circumstances. In working upon the specimens of my own collecting, the need of complete knowledge concerning some forms necessarily curtails the systematic treatment of species.

Under the title of "Some Results of Desultory Collecting of Insects in Kansas and Colorado," a record is given of my former work regarding insects which were personally collected. As mentioned at the end of this paper, which was published in the Kansas University Science Bulletin (vol. IV, No. 2), a considerable amount of material remained to be reported upon, my intention being to present the results in future lists. The greater part of the additional material consisted of hymenopterous insects, all the specimens having been collected by myself under conditions which have been explained in my former paper already mentioned. As intimated, not all of these specimens have been fully studied, but the work of specific determination has advanced to such an extent as to deserve a presentation of the results at this time rather than to subject them to further delay in publication. So far as these results are given, every record for a species contributes toward a better knowledge of geographical distribution and seasonal occurrence.

\section{LIST OF HYMENOPTERA.}

The tabulated summary which appears at the end of this list shows the number of species newly recorded for Kansas, and of species taken in both Kansas and Colorado, as well as in each state separately, and also the total number reported, all being arranged with reference to each family as treated. In regard to the species hitherto reported as occurring in Kansas, reference must be given to two papers: One, under the title of "Preliminary List of the Hymenoptera of Kansas," was published by Prof. F. H. Snow in Transactions of the Kansas Academy of Science, volume VII, pp. 97-101; and the other, entitled "A List of Kansas Hymenoptera," by J. C. Bridwell, appeared in volume XVI, pp. 203-211, of the Transactions. The names of those species which I report as being new to 
the Kansas list have not been cited in either of the preceding papers.

The scheme of classification outlined by Dr. W. H. Ashmead has been used as a guide for the arrangement of my list, notwithstanding some lack of conformity on my part with regard to revised nomenclature. The work of determination was carried on by myself so far as circumstances permitted, and it covered most of the material; otherwise the specimens were submitted to specialists for study. Mr. H. L. Viereck has identified many species, a number of which he described as new. Mr. Chas. T. Brues has also aided in similar work which dealt principally with parasites. Credit is given in the proper places to other authorities who have assisted me. Wherever the name of a new species is cited, reference is made to the distinction of the type according to Lord Walsingham's designations concerning type specimens. The descriptions published individually by Viereck and Brues establish 58 new species and varieties by name, which pertain to specimens collected by myself, in families as follows: Pemphredonidæ, 2 by Viereck; Trypoxylidæ, 1 by Viereck; Eumenidæ, 1 by Viereck; Ichneumonidæ, 23 by Viereck and 2 by Brues; Alysiidæ, 4 by Viereck; and Braconidæ, 24 by Viereck and 1 by Brues. In addition, one new variety in the family Anthophoridæ, and one new species in the family Eumenidæ, are founded upon my own names and descriptions; which are incorporated in my list herewith.

Family APID 2.

Apis mellifica L. Kansas and Colorado.

\section{Family BомвID}

(Mr. E. S. G. Titus kindly reported a few names of species, including B. consimilis Cr. from Venango county, Pennsylvania.)

Bombus appositus Cr. Colorado, Buffalo; August.

californicus Sm. Colorado, Tabernash; August. (Det. by H. J. Franklin.)

fervidus Fab. Males, formerly listed as Apathus elatus Fab. (Kansas, Wichita; August. Colorado, Colorado Springs and Denver; August.

flavifrons Cr. Colorado, Colorado Springs, in Garden of the Gods; July. Cheyenne cañon, near Colorado City; August. Buffalo; August.

howardii Cr. Colorado, Buffalo; August. morrisoni Cr. Colorado, Colorado Springs; August.

pennsylvanicus Cr. Kansas, Lawrence; May; July; July, twilight;

August; September Wichita; August. proximus Cr. Colorado, Buffalo; August. rufocintus Cr. Colorado, Colorado Springs; August. (Det. by H. J. Franklin.) 
Family BомвID

Bombus scutellaris Cr. Kansas, Wichita; August. separatus Cr. Kansas, Lawrence; May, twilight. virginicus Oliv. Kansas, Lawrence; July; July, twilight; September; October.

\section{Family SARCOPHAGIDÆ.}

Sarcophaga ægra Wk. July.

Helicobia (Sarcophaga) quadrisetosa Coq. June; July; July, twilight.

Family Muscid

Calliphora coloradensis Hough. April.

FamilyantA ANTOMYDA.

Homalomyia canicularis L. July.

scalaris Fab. May; May, twilight; June; June, twilight; July. Wichita; April.

Cœnosia flavicoxa Stein. April; May; July. Wichita; April.

Family HeLOMYZID $\approx$.

Ecothea fenestralis Fal. May.

Leria caccabata Tkr., n. sp. May.

Family ORTALID $Æ$.

Chrysomyza demandata Fab. October.

Family Oscinid

Ectecephala albistylum Macq. June; July, twilight.

Family A GROMYZIDÆ.

Odinia ornata Zett. July.

Family ANTHOPHORIDÆ.

Clisodon terminalis Cr. Colorado, Tabernash; August.

Anthophora abrupta Say. Kansas, Lawrence; May, twilight; June, twilight. occidentalis Cr. Colorado, Colorado Springs; August. smithii Cr. Colorado, Colorado Springs, August.

Melissodes agilis Cr. Colorado Springs, August. Denver, August. agilis Cr., var. snowii Cr. Colorado, Denver; August. aurigenia Cr. Colorado, Colorado Springs, in Garden of the Gods; July; Denver, August.

On account of the close resemblance of $M$. agilis to $M$. snowii and $M$.aurigenia, a comparative study of authentic and typical specimens in the collection of the University of Kansas was undertaken for the purpose of finding reliable characters for accurate identifications of other examples, including those collected by myself. In the case of agilis and aurigenia, reliance was placed upon examples authenticated by Mr. E. T. Cresson; and for snowii, a specimen was found bearing the Colorado label of F. H. Snow, and although lacking a name label, jt had evidently been collected with the type specimen, or at least under the same circumstances. This insect is 
entitled to consideration as a paratype because the particular pin label, "Col. Snow," unquestionably places it with material from which the type was taken. The fact that this specimen was found unnamed at the time of my examination does not disprove its true relation.

Since female specimens were not fully represented in the three forms, the results of study have been obtained by comparisons of male examples, in accordance with a scheme for the consideration of characters in relative groups as shown by the following arrangement of the original descriptions.

Melissodes agillis $\mathrm{Cr}$.

(Described from 6 specimens.)

\begin{tabular}{l|l} 
(1) Small, black, clothed \\
w i t h pale ochraceous or \\
cinerous pubescence, dense \\
on thorax.
\end{tabular}

(6) Abdomen thin ly clothed with cinerous pubescence, apical margin of the segmentsirather broadly whitish, and having a narrow band of cinerous pubescence, two apical segments each with a short stout tooth at extreme sides.

(7) Length, 0.40 inch.
Melissodes aurigenia $\mathrm{Cr}$. (Described from 20 specimens.)

(Description for female applies to male.)

Black; head, legs and basal segments of abdomen clothed with ochraceous pubescence, the thorax with dense fulvous pubescence, paler on sides and beneath.

Male more pubescent than female.

Clypeus, labrum, and spot on base of mandibles pale yellow.

Antennæ two-thirds the length of body, third joint less than twice the length of second, flagellum pale fulvous beneath.

(Description for female applies to male.)

Wings uniformly pale, nervures pale fulvous, second submarginal cell more than half the length of first, the third truncate at tip and narrowed one-half to marginal.

Legs slender, with ochraceous pubescence, tips of tarsi pale fulvous, ti b i a 1 spurs white.

Apical margin of abdominal segments pale testaceous, first segment clothed with a long fulvo-ochraceous pubescence, base of second and apical margin of segments 2-6 with a broad, more or less indistinct band of ochraceous pubescence, two apical segments each with a stout black tooth on extremesides.

Length, $0.40-0.45$ inch.
Melissodes snowii Cr.

(Described from 1 specimen.)

Black, clothed with dense white pubescence.

Clypeus, labrum, and spot at base of mandibles yellowish white.

Antennæ two-thirds the length of body, second and third joints subequal, flagellum fulvous, the base of joints above black.

Wings uniformly whitishhyaline, nervures pale fulvous, second submarginal less than half the length of first, the third broadly rounded at tip, and narrowed one-half toward marginal.

Tips of tarsi pale ferruginous.

Apical margin of abdominal segments whitish and having a fascia of dense white pubescence; two apical segments each with a tooth on extreme sides; venter clothed with white pubescence.

Length, 0.40 inch. 
My critical remarks herewith follow:

(1) The pubescence on the thorax of aurigenia has a richer fulvous tinge and generally appears longer and denser than with agilis or snowii, such vestiture on snowii being usually cinerous.

(2) In all examples representing the three forms, so far as examined, the labrum is more or less black on the outer edges, and in some cases wholly black with agilis. The size of the yellow spot when present on labrum is seldom uniform among specific examples, and this inconstancy is especially noticeable with agilis, which may not only lack a yellow spot on labrum, but also on base of mandibles. Prof. T. D. A. Cockerell has characterized snowii as having a dark labrum with a large yellow spot. In such respects this disposition of colors is conspicuously marked on a specimen which, as already stated, should be regarded as a paratype of snowii.

(3) Little dependence can be placed on the color of the third joint of antennæ always being black with agilis, since fulvous color may as likely appear on the second as well as the third joint as with aurigenia or snowii. If the descriptive reference to "three basal joints black" were strictly employed, a new name would be required to designate those specimens with such slight variation. There seems to be good reason, however, in applying the description of snowii precisely with regard to an almost entirely fulvous flagellum, which I consider the distinguishing feature. The specimens of this form collected by me have the flagellum scarcely darkened above and merely marked with fine transverse lines or dashes at the extreme base and apex of each joint.

(4) The size and relative shape of the second submarginal cell in comparison with the first are variable; hence they cannot be relied upon to furnish stable characters. In no case has the second submarginal cell appeared to be less than half the length of the first as stated for snowii, and even most examples of agilis show it to be larger than one-half. If descriptive characters of this nature were strictly insisted upon, a useless array of new names would be necessary to designate specimens with such uncertain variations. What I regard as a case of individual mutation is displayed by an example of snowii on account of the nervure enclosing the third submarginal cell being forked distinctly appendiculate outwardly from the upper corner instead of being rounded.

(5) All are alike in these respects.

(6) The second abdominal segment of aurigenia has a distinct basal band which is lacking on snowii, while agilis in perfect condition has a thin basal line or rather a fringe of usually erect pubescence, which, if depressed from the effect of moisture or smearing, greatly resembles a band. The description of aurigenia fails to state that the first abdominal segment is apically fasciate, as shown by perfect or unrubbed specimens.

(7) All agree in uniform size.

In consequence, I present my deductions mainly embodied in a table for the separation of the males of these three forms. In my opinion, aurigenia should be entitled to recognition as a species distinct from agilis or snowii, but the latter two names evidently apply to one species, although snowii can be conveniently retained as a varietal name of agilis.

1. Pubescence of dorsum of thorax rich fulvous, extra long and dense; second abdominal segment with a distinct basal and apical band, aurigenia.

Pubescence cinerous to ochraceous; second abdominal segment with apical band only, basal fringe not considered as a band, 2 . 
2. Flagellum of antennæ fulvous beneath, black above, third basal joint sometimes black, agilis.

Flagellum of antennæ almost wholly fulvous, scarcely darkened above, and merely marked with fine transverse black lines or dashes at extreme base and apex of each joint, agilis, var. snowii.

In a paper entitled “'The Bees of Boulder County, Colorado," published by Prof. T. D. A. Cockerell, in University of Colorado Studies, volume IV, No. 4, other varieties of agilis are designated according to the absence or presence of a yellow spot on labrum and mandibles.

Melissodes bimaculata Lep. (= binotata Say). Kansas, Lawrence; July. grindeliæ Ckll. Colorado, Manitou; August.

lupina Cr., new var. composita. Colorado, Colorado Springs; August, 1906. Types: three male specimens.

Black, clothed with grayish pubescence, somewhat fulvous on dorsum of thorax; clypeus yellow, except lower fulvous edge and a black line on each side reaching nearly half way down from the upper angle; labrum yellow unless darkened on sides; mandibles with basal yellow spot and fulvous stripe before the tip; antennæ two-thirds the length of the body, three basal joints wholly black, the third joint about twice the size of the second, following joints ferruginous beneath, black above; eyes greenish; tegulæ shining dusky brown to piceous, pubescent; wings dusky hyaline with apical margin faintly cloudy, nervures dark fuscous, second submarginal cell nearly square and receiving the first recurrent nervure at two-thirds of its length, third cell rounded behind on upper portion and narrowed less than one-half its length against the marginal.

Abdomen shining, segments 1 to 4 broadly margined behind with testaceous, which also shows on the posterior edge of the fifth segment; basal segment clothed with long, sparse, white pubescence, subfasciate on apical margin for entire length in case it has not been denuded; second to fourth segments each with a subapical fascia of whitish appressed but rather loose pubescence, curved inwardly at middle but reaching apical margin at sides, a subbasal line of thinner pubescence diffused at middle on the second segment, apical segments covered with dense pubescence which en. tirely conceals the sixth with a darker shade of fulvous; a black tooth projects from the base on each side of three apical segments, the posterior pair being acute, the middle one extra large and stout, and the anterior small and short, except on one specimen, which has only four distinct teeth at sides, besides having all the fasciæ fulvous in color; venter clothed with long grayish pubescence on the sides, apical margins with appressed fulvous pubescence. Length, $10 \mathrm{~mm}$.

These examples differ decidedly from $M$. agilis and its evident variety $M$. snowii, and also from $M$. aurigenia, on account of darker nervures of wings, arcuate fasciæ of ab- 
dominal segments 2 to 4 , and stouter middle and posterior legs with only the last joint of their tarsi pale ferruginous.

From typical lupina, the main differences may be noted by reference to the description by Cresson. As my specimens have been examined by Prof. T. D. A. Cockerell, his remarks concerning them are published in an accompanying paper, under the title of "Notes upon Variation of Melissodes lupina $\mathrm{Cr}$.

Melissodes menucha Cr. Colorado, Colorado Springs, in Garden of the Gods; July.

obliqua Say. Kansas, Lawrence; July. Wichita; August.

Family Nomadid 2 .

Epeolus compactus Cr. Kansas, Wichita; August. New to the Kansas list. Triepeolus lunatus Say. Kansas, Lawrence; July. Wichita; August. occidentalis Cr. Colorado, Colorado Springs; August.

remigatus Fab. Kansas, Wichita; August.

Family Ceratinide.

Ceratina dupla Say. Kansas, Lawrence; May.

Family MegachiLIDÆ.

Osmia lignaria Say. Kansas, Lawrence; April.

Megachile latimanus Say. Colorado, Colorado Springs and Denver; August. manifesta Cr. Colorado, Colorado Springs and Denver; August. montivaga Cr. Colorado, Buffalo; August. perbrevis Cr. Colorado, Denver; August. petulans Cr. Kansas, Lawrence; July. New to the Kansas list. pruina Sm. Colorado, Colorado Springs; August.

Anthidium emarginatum Say. Colorado, Buffalo; August.

porteræ Ckll. (= maculifrons Cr.). Colorado, Colorado Springs;

August.

Dianthidium pudicum Cr. Colorado, Buffalo; August.

Sayi Ckll. (= interruptum Say). Colorado, Colorado Springs; August.

$$
\text { Family Stelidæ. }
$$

Neolarra pruinosa Ash. Colorado, Denver; August. (Det. by E. S. G. Titus.) Cœlioxys deplanata Cr. Colorado, Colorado Springs; August. (Det. by T. D. A. Cockerell.)

dubitata Sm. (Probably female of rufitarsus Sm.). Colorado, Denver; August.

Family PANURGIDA.

(Assistance in the work of determination was kindly rendered by Mr. E. S. G. Titus.)

Halictoides marginatus Cr. Colorado, Buffalo; August.

Purdita zebrata Cr. Colorado, Denver; August.

Panurginus albitarsis Cr. Colorado, Colorado Springs; August.

ornatipes Cr. Colorado, Colorado Springs; August.

Calliopsis andreniformis Sm. Kansas, Lawrence; June; July. 
Family ANDRENIDF.

(Most of the species of Halictus were determined by E. S. G. Titus and J. C. Crawford.)

Parandrena andrenoides Cr. Colorado, Colorado Springs; April.

Augochlora fervida Sm. Kansas, Wichita; September.

pura Say. Kansas, Lawrence; May; June; July; August.

Agapostemon viridulus Fab. Kansas, Lawrence; July; August. Colorado, Denver and Colorado Springs; August.

texanus Cr. Kansas, Lawrence; July.

Halictus bruneri Cwfd. Kansas, Lawrence; May. New to the Kansas list. galpinsiæ Ckll. Colorado, Colorado Springs and Buffalo; August. ligatus Say. Kansas, Wichita; August. Colorado, Colorado Springs; August.

macoupiensis Robt. Kansas, Lawrence; May. New to the Kansas list.

perdifficilis Ckll. Colorado, Denver; August.

pilosus Sm. Kansas, Lawrence; July. New to the Kansas list. provancheri D. T. Colorado, Colorado Springs; April; August. pruinosiformis Cwfd. Colorado, Colorado Springs; August. sparsus Robt. Kansas, Lawrence; June; July; September. New to the Kansas list.

tegularis Robt. Colorado, Buffalo; August.

versatus Robt. Kansas, Lawrence; April; June; July; August;

September. New to the Kansas list.

zephyrus Sm. Kansas, Lawrence; June, twilight; July; July, twilight. New to the Kansas list.

Family OXYBELIDA.

Notoglossa emarginata Say. Kansas, Wichita; September.

Family CRABRoNide.

Paranothyreus cognatus Fox. Kansas, Lawrence; June. New to the Kansas list.

snowii Fox. Kansas, Lawrence; June. New to the Kansas list.

Thryeopus coloradensis Pack. Colorado, Colorado Springs; August.

Stenocrabro tarsalis Fox. Kansas, Lawrence; June. New to the Kansas list.

Rhopalum rufigaster Pack. Kansas, Lawrence; July. New to the Kansas list.

\section{Family PeMPhredonide.}

Stigmus inordinatus Fox. Colorado, Denver; August.

Passalœcus annulatus Say. Kansas, Lawrence; August. equalis Vr. Kansas, Lawrence; August (type). Addition to the Kansas list.

Diodontus brunneicornis Vr. Kansas, Wichita; September (type). Addition to the Kansas list.

Mimesa argentifrons Cr. Kansas, Lawrence; June. New to the Kansas list.

unicincta Cr. Kansas, Lawrence; June. New to the Kansas list. Psen punctata Fox. Colorado, Colorado Springs; August. 
Family Bembecid

Bembex nubilipennis Cr. Kansas, Wichita; August.

spinolæ Lep. (=fasciata Fab.). Kansas, Lawrence; June; July.

Colorado, Denver; August.

Microbembex monodonta Say. Kansas, Lawrence; August.

Family LARRIDÆ.

Notogonia argentata Beauv. Kansas, Lawrence; August; September; YOctober.

Tachytes obscurus Cr. Kansas, Lawrence; July. New to the Kansas list. spatulatus Fox. Colorado, Colorado Springs; August.

Tachysphex tarsatus Say. Colorado, Buffalo; August.

Family Philanthid E.

Cerceris bicornuta Guer. ( $?=$ venator Cr.). Kansas, Wichita; August.

finitima Cr. Kansas, Lawrence; July. Wichita; August.

Aphilanthops laticinctus Cr. Colorado, Colorado Springs; August.

Philanthus crabroniformis Sm. Colorado, Denver; August.

punctatus Say. Kansas, Lawrence; June.

Family TrYPOXYLID $A$.

Trypoxylon albipilosum Fox. Kansas, Lawrence; June; August.

bidentatum Fox. Kansas, Lawrence; June. New to the Kansas list.

clavatum Say. Kansas, Lawrence; June; August.

quintilis Vr. Kansas, Lawrence; July (type). Addition tô the

Kansas list.

texense Sauss. Colorado, Colorado Springs; August.

Family Mellinid

Mellinus rufinodus Cr. Colorado, Denver; August.

Euspongus bipunctatus Say. Kansas, Lawrence; June; July.

Family NysSONIDA.

Alyson melleus Say. Kansas, Lawrence; June; July.

Family STIzid ж.

Sphecius speciosus Drury. Kansas, Lawrence; July; August.

Family SPHECID $\approx$.

Proterosphex ichneumonea L. Kansas, Lawrence; July.

pennsylvanica L. Kansas, Lawrence; June; July; August.

Isodontia azteca Sauss. (=macrocephalus Fox). Kansas, Lawrence; May;

July. New to the Kansas list.

Chalybion cæruleum L. Kansas, Lawrence; June; July.

Priononyx atrata Lep. Kansas, Wichita; August.

atrata Lep., var. brunnipes Cr. Kansas, Lawrence; August.

New to the Kansas list.

Psammophila argentifrons Cr. Colorado, Colorado Springs; August.

communis Cr. Colorado, Cheyenne cañon, near Colorado

City; July. Manitou; August.

luctuosa Sm. Colorado, Denver, Buffalo, and Colorado Springs;

August. 
Ammophila aberti Hald. (Evidently identical with yarrowi Cr.). Colorado,

Colorado Springs; August.

extrematata Cr. Colorado, Colorado Springs; August.

gryphus Sm. (Probably female of macra Cr.) Kansas, Wich-

ita; August. New to the Kansas list.

intercepta Lep. Kansas, Lawrence; August; September. Wich-

ita; August.

macra Cr. (Probably male of gryphus Sm.). Colorado, Cheyenne cañon, near Colorado City; July.

pruinosa Cr. Colorado, Denver; August.

vulgaris Cr. Colorado, Cheyenne cañon, near Colorado City;

July. Colorado Springs; August.

yarrowi Cr. (See aberti Hald.)

Sceliphron '(Pelopœus) cementarius Drury. Kansas, Lawrence; June and

July, entering rooms.

\section{Family Ceropalid}

Priocnemis fulvicornis Cr. Kansas, Lawrence; July; August. Wichita, August.

nigripes Cr. Kansas, Lawrence; April.

texanus Cr. Kansas, Wichita; August. New to the Kansas list.

Agenia architecta Say. Kansas, Lawrence; May; October. Colorado, Colorado Springs; August.

Ferreola subviolaceus Cr. Colorado, Colorado Springs; August.

Sophropompilus ingenuus Cr. Colorado, Colorado Springs; August.

relativus Fox. Kansas, Lawrence; June. New to the Kansas list. Colorado, Colorado Springs and Manitou; August.

Anoplius fuligidus Cr. Colorado, Colorado Springs; August.

funereus Lep. Kansas, Wichita; August. New to the Kansas list. marginatus Say. Kansas, Lawrence; June.

tenebrosus Cr. Colorado, Colorado Springs; August.

Ceropales fraterna Sm. Kansas, Lawrence; June.

Family Vespid

Vespa diabolica Sauss. Colorado, Green Mountain Falls; Cheyenne cañon and Manitou; July. Denver and Buffalo; August.

germanica Fab. Kansas, Lawrence; May; June, twilight; September. maculata L. Colorado, Colorado Springs; August. Specimens of this species and of vulgaris L., collected in Venango county, Pennsylvania, recall episodes of my early attempts at collecting.

occidentalis Cr. Kansas, Lawrence; August; October. Colorado, Manitou; July.

Polistes aurifer Sauss. Colorado, Colorado Springs; August.

canadensis L. Kansas, Lawrence; July; August.

exclamans Vr. Kansas, Lawrence; May; August; November, inside windows. Additions to the Kansas list.

These examples agree in almost every particular with type specimen, which, however, lacks antennæ. The antennal joints are reddish brown excepting the middle of the flagellum, which is infuscated, principally on the upper surface. With one specimen the brown space of clypeus is reduced to a mere vertical line, and the posterior surfaces of middle and hind coxæ are 
almost wholly yellow, at least without distinct separation of two oblique bands. This form resembles very closely $P$. minor Beauv., collected by me in northern Texas, and raises a question whether exclamans is not indeed a highly colored variety of minor.

Polistes variatus Cr. Kansas, Lawrence; April to August.

Polybia flavitarsis Sauss. Colorado, Manitou and Buffalo; August.

Family Eumenid

Zethus spinipes Say. Kansas, Lawrence; July. New to the Kansas list. Eumenes coloradensis Cr. Colorado, Colorado Springs and Buffalo; August. fraternus Say. Kansas, Lawrence; July.

Nortonia symmorpha Sauss. Kansas, Lawrence; July.

Odynerus (Leionotus) annulatus Say. Colorado, Colorado Springs; August. anormis Say. Kansas, Lawrence; May; July; August. leionotus Vr. Kansas, Lawrence; July (type). Addition to the Kansas list.

pedestris Sauss. Kansas, Lawrence; June.

Ancistrocerus behrensii Cr. Colorado, Buffalo; August.

campestris Sauss. Kansas, Lawrence; May. One specimen

lacks yellow apical margin on third abdominal segment. capra Sauss. Kansas, Lawrence; data missing. New to the

Kansas list.

catskillensis Sauss. Kansas, Lawrence; May; July. New to

Kansas list. The specimen collected in the latter month has the yellow border of first abdominal segment somewhat enlarged on the sides. Colorado, Denver; August.

Variety a. Colorado, Colorado Springs and Denver; August. Two specimens show mutations as follows: One with oblique yellow line connecting with the border on sides of the second abdominal segment; the other with small disconnected spots instead of the oblique yellow line.

In studying the variations of color markings in this species, variety $d$ was identified from material collected by myself in Venango county, Pennsylvania.

All of the above examples are females.

fulvipes Sauss. Kansas, Lawrence; August. New to the

Kansas list.

tenuatus, n. sp. Colorado, Denver; August, 1906. Type; one female specimen.

Collected with catskillensis Sauss. and other varieties, to which it bears a very close resemblance, but the elongated thorax of this specimen presents a structural difference of sufficient importance to entitle the insect to recognition as a distinct species.

Thorax a little more than twice as long as the greatest width between base of wings; body feebly shining, black with yellow markings, pubescence extremely scanty, fulvous on dorsum of thorax, fuscous on front of head above antennal insertions, otherwise cinerous 
and generally very fine and short, but longer on cheeks, lateral àngles of metathorax, and basal segment of abdomen; punctures on head small, coarse on thorax, and all confluent; abdomen finely and rather thickly punctured. Flagellum of antennæ scarcely tinged with fulvous color on under side at tip.

Clypeus equal in length and breadth, lower sides oblique, extremity subbidentate, punctures coarse and elongate, confluent, upper and lower edges black, yellow inwardly except a large central black space which extends downward from upper edge, gradually increasing in width until it suddenly terminates with two incurved margins meeting in a point below the middle.

The other yellow ornamentation are as follows: Spot at base of mandibles; lower surface of scape; spot on front almost between antennal insertions; small dash behind the upper portion of each eye; upper margin of prothorax narrowly in front but rather broadly outwardly; tegulæ except fulvous spot in middle; spot beneath on pleuræ; spot on each side of scutellum, and all of postscutellum (which is rounded behind), and the apical margins of five abdominal segments above and below, with an apical spot on upper side of apex.

The first abdominal margin is abruptly enlarged on sides and very narrow beneath; all margins on the upper side are more or less sinuate in front, and together with those on the venter curve forwards on the lateral edges. The second to fourth ventral margins are wide, excepting an arcuate constriction on fore edge near each side.

Legs yellow, except the femora, which are pale only at tip, but rather obliquely so on the sides of the anterior and middle pair, and all the tarsi are tinged with fulvous; apical spur of hind tibiæ and its basal area black.

Posterior face of the metathorax dull, very faintly striated, divided by a median carina into two areas which are enclosed by a ridge with a protruding blunt angle on each side. Abdomen elongate, first segment short but about as wide as the second; the transverse groove appears to be the offset of a carina. The black areas on the upper part of the abdominal segments, and the dorsum of thorax where not rubbed, apparently owe much of their subopaqueness to a fine pollinose coating. Wings dusky, tinged with brown along fore margin, and clouded apically.

Length, $8.5 \mathrm{~mm}$; wing, $7 \mathrm{~mm}$.

Symmorphus walshianus Sauss. Kansas, Lawrence; 'June. New to the Kansas list.

Monobia quadridens L. Kansas, Lawrence; July; August. 
Family Chrysidid $\approx$.

Chrysis pattoni Aaron. Colorado, Colorado Springs; August.

Hedychrum obsoletum Say. Colorado, Denver; August.

violaceum Brulle. Colorado, Colorado Springs; August.

Family BETHYLIDA.

Epyris armifera Say. Kansas, Lawrence; July. New to the Kansas list.

Family MyzINID $Æ$.

Myzine sexcincta Fab. Kansas, Lawrence; September. Wichita; August;

September.

Family Scolinde.

Elis plumipes Drury. Kansas, Lawrence; July.

Family TIPHIIDÆ.

Tiphia inornata Say. Kansas, Lawrence; June.

tarda Say. Kansas, Lawrence; June; July. New to the Kansas list.

Family MYrmosid

Myrmosa unicolor Say. Kansas, Lawrence; July.

Family Mutillide.

?Mutilla ornativentris Cr. Kansas, Lawrence; August.

Timuila californica Rad. Colorado, Colorado Springs; August.

Sphærophthalma creusa Cr. Colorado, Colorado Springs, August.

quadriguttata Say. Kansas, Wichita; August.

sparsa Fox. Kansas, Lawrence; May. New to the Kansas

list.

vesta Cr. Colorado, Colorado Springs; August.

Family PONERID $A$.

(In this and the following three families the determinations of species and forms were made by comparison with specimens that have been identified by Prof. W. M. Wheeler, or in cases where this course was not possible, the specimens received his personal attention.)

Proceratium croceum Roger. Kansas, Lawrence; August, a single male specimen; "probably this species," according to Prof. W. M. Wheeler, who further remarked: "This is an extremely rare ant-with the exception of a male of $P$. crassicorne in my collection, the only known male of this interesting genus. The workers are yellow and live in small colonies in rotten wood in rich forests." New to the Kansas list.

Family MYRMICIDA.

Cremastogaster lineolata Say. Kansas, Lawrence; April, females and workers; June, worker; September, male and females. New to the Kansas list.

lineolata Say, subspecies læviuscula Mayr. Kansas, Lawrence; October, workers under bark of old dead elm. Wichita; April, workers. New to the Kansas list.

Solenopsis molesta Say, (=debilis Mayr.). Kansas, Lawrence; July, females and workers; August, male. New to the Kansas list. Colorado, Denver; August, females.

texana Emery. Kansas, Lawrence; June, twilight, female. New to the Kansas list. 
Myrmecina graminicola Forster, subspecies americana Mayr. Kansas, Lawrence; September and October, males. New to the Kansas list.

Monomorium minutum Mayr., var. minimum Buckley. Kansas, Lawrence; July, and July, twilight, workers. New to the Kansas list.

Myrmica rubra Linne. Kansas, Lawrence; September. New to the Kansas list.

rubra Linne, subspecies brevinodis Emery, variety. Colorado,

Colorado Springs; April. Professor Wheeler referred to the specimen as follows: "It seems to be an undersized or microgyne female."

Stenamma (Aphænogaster) tennesseense Mayr. Kansas, Lawrence; May, worker. New to the Kansas list.

Pogonomyrmex occidentalis Cresson. Colorado, Colorado Springs; April, workers.

\section{Family DOLICHODERIDÆ.}

Dorymyrmex pyramicus Roger. Colorado, Colorado Springs; August, males and workers.

Iridiomyrmex analis Andre, variety. Kansas, Lawrence; July, worker. New to the Kansas list.

\section{Family Formicid $\approx$.}

Camponotus castaneus Latreille, subspecies americanus Mayr. Kansas. New to the Kansas list.

herculaneus Linne, subspecies pennsylvanicus De Geer. Kansas, Lawrence; April, worker; July, females attended by workers emerging from sills of a house, and female in flight; July, at night, males; June, twilight, also July, and July, twilight, minor workers.

marginatus Latreille, var. minutus Emery. Kansas, Lawrence; July, twilight, worker; October, workers. New to the Kansas list.

marginatus Latreille, var. nearcticus Emery. Kansas, Lawrence; June, female. New to the Kansas list.

Prenolepis (Nylanderia) imparis Say. Kansas, Lawrence; March and April, males. New to the Kansas list.

Lasius interjectus Mayr. Kansas, Lawrence; April, workers. New to the Kansas list.

niger Linne, var. americanus Emery. Kansas, Lawrence; March, female; April, male and female; July, and July, twilight, and September, at night, males. New to the Kansas list.

niger Linne, var. neoniger Emery. Colorado, Denver; August, males, females and workers issuing from cracks in slab stone walk.

umbratus Nylander, variety. Kansas, Lawrence; June, female. New to the Kansas list.

Formica fusca Linne, var. argentata Wheeler. Colorado, Colorado Springs; April and August, workers. Denver; August, workers.

fusca Linne, var. neoclara Emery. Colorado, Colorado Springs; April, workers. Denver; August, workers.

fusca Linne, var. subsericea Say. Kansas, Lawrence; July, male. New to the Kansas list. Colorado, Denver; August, males. 
Formica fusca Linne, subspecies subpolita Mayr. Kansas, Lawrence; July, female. New to the Kansas list.

schaufussi Mayr. Kansas, Lawrence; July, female. New to the Kansas list.

\section{Family PeLecinid}

Pelecinus polyturator Drury. Kansas, Lawrence; July; August. Colorado, Denver; August.

\section{Family ProctotryPid}

Proctotrypes belfragei Ash. Kansas, Lawrence; November. New to the Kansas list.

caudatus Say. Kansas, Lawrence; October. pallidus Say. Kansas, Lawrence; August.

terminalis Ash. Kansas, Lawrence; June. New to the Kansas list.

\section{Family BeLYTIDA.}

Zelotypa texana Ash. Kansas, Lawrence; April. New to the Kansas list. Pantoclis analis Ash. Kansas, Lawrence; July. New to the Kansas list.

Family DIAPRIIDA.

Spilomicrus atropetiolatus Ash. Colorado, Denver; August.

Family Scelionid

Prosacantha punctiventris Ash. Kansas, Lawrence; April. New to the Kansas list.

Family Figitid $\approx$.

Aspicera albihirta Ash. Kansas, Lawrence; June, twilight, and at night. New to the Kansas list.

Family Chalcidid

Chalcis flavipes Fab. (=ovata Say). Kansas, Lawrence; November.

Spilochalcis torvina Cr. Kansas, Lawrence; October. Colorado, Colorado Springs; August.

Haltichella onatas Wk. Kansas, Lawrence. (Name erroneously spelled ovatus in Trans. Kan. Acad. Sci., vol. XXI, pt. I, p. 160, where an account is given of the breeding of the species from section of elm tree infested by Magdalis armicollis Say. Specimen emerged in May, 1905, from section of tree kept in breeding-cage since the preceding September.) Determined by Dr. W. H. Ashmead. New to the Kansas list.

Family EURYTomid Æ.

Eurytoma crassineura Ash. Colorado, Colorado Springs; August. magdalidis Ash. Colorado, Colorado Springs; August.

Family PERILAmPIDÆ.

Perilampus platygaster Say. Kansas, Wichita; September, by sweeping in vineyard. Colorado, Colorado Springs; August.

Family Eucharide.

Orasema coloradensis Ash. Kansas, Lawrence; August, twilight. New to the Kansas list. 


\section{Family ICHNEUMONIDA.}

Obba (Ichneumon) orpheus Cr. Colorado, Denver; August.

Ichneumon animosus Cr., var. rubellus Cr. Colorado, Colorado Springs; August.

grotei Cr. Colorado, Denver; August.

pedalis Cr. Colorado, Denver; August, including color varieties either with black or reddish tarsi of posterior legs.

Cratichneumon azotus Cr. Colorado, Denver; August.

extrematatis Cr. Kansas, Lawrence; May; October. New to the Kansas list.

Barichneumon paratus Say. Kansas, Lawrence; July, twilight.

Stiboscopus oryxicornis Vr. Kansas, Lawrence; July (type and homotype); July, twilight. Addition to the Kansas list.

Diaglypta manitouensis Vr. Colorado, Manitou 6629 feet; August (type).

Pezomachus alogus Vr. Kansas, Lawrence; May, at electric light (type).

Addition to the Kansas list.

Cryptus albitarsus Cr. Kansas, Lawrence; May, at night. New to the Kansas list.

Lampronota amphimilæna Walsh. Colorado, Denver; August.

pleuralis Cr. Colorado, Colorado Springs; August.

Harrimaniella pæneimitatrix Vr. Kansas, Lawrence; October (metatype);

October and November (homo-topotypes). Addition to the Kansas list.

Thalessa lunator Fab. Kansas, Lawrence; May, a small-sized female hovering around a partly dead soft maple tree; males and females on dying box-elder, the females ovipositing.

Ephialtes pygmæus Walsh. Kansas, Lawrence; October. New to the Kansas list.

Pimpla annulipes Br. Kansas, Lawrence; April; May; June; August; August, at night; October.

conquisitor Say. Kansas, Lawrence; October.

inquisitor Say. Kansas, Lawrence; May. New to the Kansas list. Colorado, Denver and Colorado Springs; August.

parvialba Vr. Kansas, Lawrence; June, twilight (type). Addition to the Kansas list.

Glypta aprilis Br. Kansas, Lawrence; April 23, 1892 (type). Addition to the Kansas list.

Callidiotes kansensis Brues. Kansas, Lawrence; July, twilight (type). Addition to the Kansas list.

Scopiorus monticola Brues. Colorado, Colorado Springs; August (type). Sychoportus tuckeri Vr. Kansas, Lawrence; August (type); May, at night (metatype). Addition to the Kansas list.

Bassus lætatarius Fab. Kansas, Lawrence; June; June, twilight.

Syrphoctonus maculifrons Cr. Colorado, Denver and Colorado Springs; August.

Stenomacrus hastatus Davis. Colorado, Tabernash; August.

Metacœlus lævis Cr. Colorado, Colorado Springs; August.

Ophion bilineatum Say. Kansas, Lawrence; March; March, at night; April; May; May, at night, and at electric light; June; August.

idoneum Vr. Kansas, Lawrence; April (metatype); March; April, at night; May; May, at night (homo-topotypes). Addition to the Kansas list. 
Ophion purgatum Say. Kansas, Lawrence; June; June, at night; July, twilight. Colorado, Colorado Springs; August.

Campoplex villosus Norton. Kansas, Lawrence; data missing. New to the Kansas list.

Amorphota augusta Vr. Kansas, Lawrence; August (type and homo-paratype). Addition to the Kansas list.

nocturna Vr. Kansas, Lawrence; May, at night (type). Addition to the Kansas list.

pænexareolata Vr. Kansas, Lawrence; August (type); June;

June, twilight; July; August (homo-topotypes). Addition to the Kansas list.

perrivalis Vr. Kansas, Lawrence; August (types); May and

July (paratypes); June, twilight. Addition to the Kansas list. Colorado, Denver; August.

Angitia autumnalis Vr. Kansas, Lawrence; September (type). Addition to the Kansas list.

Idechthis biconjugatus Vr. Kansas, Lawrence; May, at night (type). Addition to the Kansas list.

Ischnoscopus tæniatus Vr. Kansas, Lawrence; July (type). Addition to the Kansas list.

Limneria flavicincta Ash. Colorado, Denver; August.

lawrencei Vr. Kansas, Lawrence; May, at night (type). Wichita; April (homotypes). Addition to the Kansas list.

perdistincta Vr. Kansas, Lawrence; August (type); April, at night; August (metatypes); June, twilight, and at night; July; August; August, twilight (homo-topotypes). Wichita, September (homotype). Addition to the Kansas list. Colorado, Denver; March, in window; April, commonly taken by sweepin grass; August, scarce.

tibiator Cr., var. Colorado, Denver and Colorado Springs; August. virgilis Vr. Kansas, Lawrence; May, at night (type). Addition to the Kansas list.

Paniscus geminatus Say. Kansas, Lawrence; April, at night; May, at night; June; July, at night. Wichita; May.

Ceratosoma fasciata Cr. Kansas, Lawrence; August. New to the Kansas list.

Mesochrus noctivagus Vr. Kansas, Lawrence; May, at night (type). Addition to the Kansas list.

Porizon canaliculatus Vr. Colorado, Tabernash; August.

Thersilochus mimeticus Vr. Kansas, Wichita; September, 1895, in vineyard (type). Addition to the Kansas list.

quintilis Vr. Kansas, Lawrence; July (type). Addition to the Kansas list.

Pristomerus appalachianus Vr. Kansas, Wichita; September, 1895, in vineyard (male type). Addition to the Kansas list. appalachianus Vr., var. dorsocastaneous Vr. Kansas, Lawrence; August (male and female types and homo-topotype). Addition to the Kansas list. 


\section{Family Alysinde.}

Enonogastra microrhopalæ Ash. Kansas, Lawrence; July, twilight. New to the Kansas list.

Aphæreta delosa Vr. Kansas, Lawrence; August (cotypes, paratype and homo-topotypes); June, twilight; August, twilight (metatypes); July, twilight. Addition to the Kansas list.

subtricarinata Vr. Kansas, Lawrence; August (type); May, at night (paratype). Addition to the Kansas list.

Dinotrema signifrons Vr. Kansas, Lawrence; June, at night (type). Addition to the Kansas list.

Aspilota columbiana Vr. Kansas, Lawrence; August (type). Addition to the Kansas list.

Family BRACONIDÆ.

Lysiphlebus succineus Vr. Kansas, Lawrence; August (type). Addition to the Kansas list.

Meteorus noctivagus Vr. Kansas, Lawrence; May, at night (type). Addition to the Kansas list.

relativus Vr. Kansas, Lawrence; September, 1902, appearing in breeding-cage containing both larvæ and pupæ of Malacosoma disstria Hubn. (type and homo-topotypes). Addition to the Kansas list.

Macrocentrus atriceps Cr. Kansas, Lawrence; August. New to the Kansas list.

delicatus Cr. Kansas, Lawrence; August. New to the Kansas list.

Zele crassicalcaratus Vr. Kansas, Lawrence; August (type and homo-topotype); May; July; July, twilight (homo-topotypes). Addition to the Kansas list.

Cenocœlius politifrons Vr. Kansas, Lawrence; June, 1892, collected in timber along Kansas river (type). Addition to the Kansas list.

Brachistes nocturnus Vr. Kansas, Lawrence; May, at night (type). Addition to the Kansas list.

Calyptus (Brachistes) rotundiceps Cr. Kansas, Lawrence; September 26, 1904, in company with Melanobracon ulmicola Vr. (see notes quoted after this name). Other specimens emerged during the following spring from April 13 to May 24, from sections of elm tree kept in breeding-cage. New to the Kansas list.

Chelonus sericeus Say. Colorado, Colorado Springs; August.

texanus Cr. Kansas, Wichita; September, 1895, on farm near city, and taken by sweeping in slough-grass in timber along Arkansas river. New to the Kansas list.

Agathis media Cr. Kansas, Wichita; September. New to the Kansas list. Colorado, Garden of the Gods, near Colorado City; July. Colorado Springs; August.

vulgaris Cr. Colorado, Colorado Springs; July and August.

Crassomicrodus divisus Cr. Kansas, Wichita; September, 1895, in vineyard. New to the Kansas list.

fulvescens Cr. Colorado, Colorado Springs; August. medius Cr. Colorado, Colorado Springs; August. nigricaudus Vr. Colorado, Colorado Springs; August (typ , paratype and homo-topotypes). 
Microdus castaneicinctus Vr. Kansas, Lawrence; August (type). Addition to the Kansas list.

pimploides Vr. Kansas, Lawrence; August (type and homo-topotype); September (homo-topotype). Addition to the Kansas list.

wichitaensis Vr. Kansas, Wichita; September, 1895, in vineyard

(type and homo-topotype). Addition to the Kansas list.

Cardiochiles explorator Say. Colorado, Colorado Springs; August.

Apanteles congregatus Say. Kansas, Lawrence; June, bred from unknown

host on blade of grass. New to the Kansas list.

congregatus Say, var. hemileucæ Riley. Kansas, Lawrence; November, bred from cocoon mass on willow leaf. New to the Kansas list.

ensiger Say. Kansas, Lawrence; July, twilight. New to the Kansas list.

xylina Say. Kansas, Lawrence; August. New to the Kansas list.

Pseudapanteles bisstigmata Say. Kansas, Lawrence; August. New to the Kansas list.

Microgaster tuckeri Vr. Kansas, Lawrence; June (type). Addition to the Kansas list.

Microplitis croceipes Cr. Kansas, Wichita; September, 1895, swept from peanut vines. New to the Kansas list.

Biosteres indotatus Vr. Kansas, Lawrence; August (type and homo-topotypes). Addition to the Kansas list.

Diachasma appalachicola Vr. Kansas, Lawrence; July (type). Addition to the Kansas list.

secunda Vr. Kansas, Lawrence; July (type). Addition to the Kansas list.

Opius aberrans Vr. Kansas, Lawrence; August (type, paratype and homotopotypes). Addition to the Kansas list.

basiniger Vr. Kansas, Lawrence; July (type) ; June, twilight (metatype). Addition to the Kansas list.

luteiceps Vr. Kansas, Lawrence; August (type). Addition to the Kansas list.

nigrocastaneus Vr. Kansas, Lawrence; July (type). August, twilight (metatype); July (homo-topotype, having dorsum of thorax wholly brownish between parapsidal grooves). Addition to the Kansas list.

Iphiaulax rugator Say. Kansas, Lawrence; August. New to the Kansas list.

Melanobracon ulmicola Vr. Kansas, Lawrence.

Notes concerning the capture of this species were published in Trans. Kan. Acad. Sci., vol. XXI, pt. I, p. 160, to this effect: “Males and females flying about and alighting on bark of infested portions of elm tree later cut into sections for breeding purposes, September 26, 1904, the female probing with the ovipositor into the cracks of the bark and holes of Magdalis armicollis Say, whose larvæ abounded beneath the bark; other specimens emerged during the following May from sections of the tree kept in breeding-cage. Regarding the naming of these parasites, Mr. H. L. Viereck, to whom a pair of specimens was 
submitted for study, wrote as follows: 'This appears to be a new species and one that has been confused with simplex. I propose to call it ulmicola.", Further captures were made at random in May. (Metatype and homo-topotypes.) Addition to the Kansas list.

Microbracon sulcifrons Ash. Colorado, Colorado Springs; August.

Bracon kansensis Vr. Kansas, Wichita; September, 1895, in vineyard (type). Addition to the Kansas list.

piceiceps Vr. Kansas, Lawrence; data missing (type). Addition to the Kansas list.

millitor Say, var. xanthostigma Cr. Kansas, Lawrence; April; August. Colorado, Colorado Springs; August.

Rhogas intermedius Cr. Kansas, Lawrence; May, at night; August. Also a variety taken in July and August. Colorado, Colorado Springs; August.

melanothorax Vr. Kansas, Lawrence; August (type). Addition to the Kansas list.

terminalis Cr. Kansas, Lawrence; May, at electric light, and at night; June, twilight, and at electric light; July, at electric light; October.

Hedysomus wichitus Vr. Kansas, Lawrence; August, twilight (type). Addition to the Kansas list.

Hormiopterus claripennis Brues. Kansas, Lawrence; September (type). Addition to the Kansas list.

Phænodus caddous Vr. Kansas, Lawrence; June, twilight (type). Addition to the Kansas list.

Spathius simillimus Ash. Kansas, Lawrence; associated with Melanobracon ulmicola Vr. (see reference and notes after this name); specimens emerged April 3 to May 29, 1905, from sections of elm tree kept in breeding-cage. Doctor Ashmead, who determined the species, added the following remark: "All Spathius are parasitic on Coleoptera."

\section{Family SIRICIDÆ.}

(Mr. H. L. Viereck, in reporting upon the Siricoidea and Tenthredinoidea submitted to him, acknowledges the assistance of Dr. A. D. MacGillivray.) Sirex flavicornis Fab. Colorado, Manitou; July. Denver and Tabernash; August.

Paururus nigricornis Fab. Kansas, Lawrence; October. New to the Kansas list.

Tremex columba L. Kansas, Lawrence; September 24, 1904, one female found dead with ovipositor stuck fast in bark of elm tree; October. Colorado, Denver; August.

Family CEPHID

Cephus trimaculatus Say. Kansas, Lawrence; May. (Det. by H. E, Burke.) New to the Kansas list.

\section{Family XYELID}

Macroxyela ferruginea Say. Kansas, Lawrence; April.

Family НчцотоміD

Schizocera zabriskii Ash. Kansas, Lawrence; August. New to the Kansas list.

Hylotoma miniata Klug. Kansas, Lawrence; June. New to the Kansas list. 


\section{Family PTERYGOPHORIDA.}

Acordulecera dorsalis Say. Kansas, Lawrence; June; June, twilight; July; July, twilight; August.

\section{Family SELANDRIID}

Blennacampa pygmæa Say. Kansas, Lawrence; June. New to the Kansas list.

Endelomyia rosæ Har. Kansas, Lawrence; April; May, on rose bushes. New to the Kansas list.

$$
\text { Family Nematid }
$$

Gymnonychus appendiculatus Htg. Colorado, Colorado Springs; August. Pteronus latus Mar. Kansas, Lawrence; May. New to the Kansas list. mendicus Walsh. Colorado, Colorado Springs; August. (Personally determined by Dr. A. D. MacGillivray.)

Family Tenthredinide.

Dolerus aprilis Nor. Kansas, Lawrence; May.

bicolor Bvr. Kansas, Lawrence; April.

Emphytus apertus Nor. Kansas, Lawrence; August. New to the Kansas list.

Macrophya tibiator Nor. Kansas, Lawrence; April.

Tenthredo variegata Nor. Kansas, Lawrence; May. New to the Kansas list.

Family Ciмвicidæ.

Zarea americana Cr. Kansas, Lawrence; April. 
Tabulated Summary of Families and Species, Including Varieties.

\begin{tabular}{|c|c|c|c|c|c|}
\hline Name OF Family. & $\begin{array}{c}\begin{array}{c}\text { Total } \\
\text { number } \\
\text { of } \\
\text { species. }\end{array}\end{array}$ & $\begin{array}{l}\text { Species } \\
\text { taken in } \\
\text { Kansas. }\end{array}$ & $\begin{array}{l}\text { Species } \\
\text { new to } \\
\text { Kansas. }\end{array}$ & $\begin{array}{l}\text { Species } \\
\text { taken in } \\
\text { Colorado. }\end{array}$ & $\begin{array}{c}\text { Species } \\
\text { taken in } \\
\text { both Kan- } \\
\text { sas and } \\
\text { Colorado. }\end{array}$ \\
\hline Apidæ & 1 & 1 & & 1 & 1 \\
\hline$\ldots \ldots \ldots \ldots \ldots$ & 12 & 5 & & 8 & 1 \\
\hline Anthophoridæ............. & 12 & 3 & & 9 & + \\
\hline Nomadidæ............... & 4 & 3 & 1 & 1 & \\
\hline Ceratinidæ. $\ldots \ldots \ldots \ldots \ldots \ldots$ & 1 & 1 & & & \\
\hline Megachilidæ............. & 11 & 2 & 1 & 9 & $\ldots \ldots$ \\
\hline Stelidæ .................. & 3 & & & 3 & $\ldots \ldots$ \\
\hline Panurgidæ................. & 5 & 1 & & 4 & $\ldots \ldots$ \\
\hline Andrenidæ............... & 17 & 11 & 6 & 8 & 2 \\
\hline Oxybelidæ................ & 1 & 1 & & & \\
\hline Crabronidæ............... & 5 & 4 & 4 & 1 & $\ldots \ldots \ldots$ \\
\hline Pemphredonidæ............ & 7 & 5 & 4 & 2 & $\ldots \ldots \ldots$ \\
\hline Bembecidæ $\ldots \ldots \ldots \ldots \ldots \ldots$ & 3 & 3 & & 1 & 1 \\
\hline Larridæ................ & 4 & 2 & 1 & 2 & - \\
\hline Philanthidæ................ & 5 & 3 & & 2 & $\ldots \ldots \ldots$ \\
\hline Trypoxylidæ ............... & 5 & 4 & 2 & 1 & $\ldots \ldots \ldots$ \\
\hline Mellinid̆æ................ & 2 & 1 & & 1 & $\ldots \ldots$ \\
\hline Nyssonidæ................ & 1 & 1 & & & $\ldots \ldots \ldots$ \\
\hline $\begin{array}{l}\text { Stizidæ } \\
\text { Snhecidæ }\end{array}$ & $\begin{array}{r}1 \\
17\end{array}$ & $\begin{array}{l}1 \\
9\end{array}$ & 3 & 8 & $\cdots$ \\
\hline Ceropalidæ............... & $\begin{array}{l}17 \\
12\end{array}$ & 8 & $\begin{array}{l}5 \\
3\end{array}$ & $\begin{array}{l}8 \\
6\end{array}$ & $\cdots$ \\
\hline Vespidæ..................... & 9 & 5 & 1 & 5 & 1 \\
\hline enidæ............... & 16 & 12 & 6 & 5 & 1 \\
\hline Chrysididæ............... & 3 & & & 3 & \\
\hline Bethylidæ.. ............ & 1 & 1 & 1 & & $\cdots$ \\
\hline Myzinidæ............... & 1 & 1 & . & & $\ldots \ldots \ldots$ \\
\hline Scoliidæ... $\ldots \ldots \ldots \ldots \ldots \ldots$ & 1 & 1 & & .... & $\ldots \ldots \ldots$ \\
\hline$\ldots \ldots \ldots \ldots \ldots \ldots$ & 2 & 2 & 1 & $\cdots$ & $\ldots \ldots \ldots$ \\
\hline Myrmosidæ............... & 1 & 1 & 1 & $\cdots$ & $\cdots \cdots \cdots$ \\
\hline Mutillidæ $\ldots \ldots \ldots \ldots \ldots \ldots$ & 6 & 3 & 1 & 3 & $\cdots \cdots \cdots$ \\
\hline $\begin{array}{l}\text { Poneridæ } \\
\text { Myrmicidæ... }\end{array}$ & 1 & 1 & $\begin{array}{l}1 \\
8\end{array}$ & $\cdots$ & $\cdots \cdots{ }_{1}$ \\
\hline 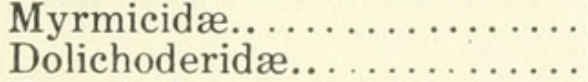 & $\begin{array}{r}10 \\
2\end{array}$ & $\begin{array}{l}8 \\
1\end{array}$ & $\begin{array}{l}8 \\
1\end{array}$ & 1 & \\
\hline$\ldots \ldots \ldots \ldots$ & 14 & 11 & 10 & 4 & 1 \\
\hline ( & 1 & 1 & & $\cdots$ & $\ldots \ldots \ldots$ \\
\hline$\ldots \ldots \ldots \ldots$ & 4 & 4 & 2 & . & ‥ \\
\hline$\ldots \ldots \ldots \ldots$ & 2 & 2 & & 1 & $\cdots$ \\
\hline Diapriidæ............... & 1 & & & 1 & $\cdots$ \\
\hline $\begin{array}{l}\text { Scelionidæ } \ldots \ldots \ldots \ldots \ldots \ldots \ldots \\
\text { Figitidæ }\end{array}$ & 1 & 1 & 1 & & $\cdots$ \\
\hline $\begin{array}{l}\ldots \ldots \ldots \ldots \ldots \\
\ldots \ldots \ldots \ldots \ldots\end{array}$ & $\begin{array}{l}1 \\
3\end{array}$ & $\begin{array}{l}1 \\
3\end{array}$ & $\begin{array}{l}1 \\
1\end{array}$ & 1 & $i$ \\
\hline & 2 & & & 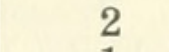 & ... \\
\hline$\ldots \ldots \ldots \ldots$ & 1 & 1 & & 1 & 1 \\
\hline $\mathrm{Eu}$ & 1 & 1 & 0 & & .... \\
\hline Ichneumonidæ & 52 & 37 & 29 & 19 & 4 \\
\hline Al & 5 & 5 & 5 & & \\
\hline 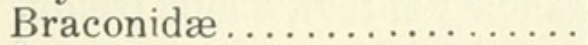 & 48 & 41 & 37 & 10 & 3 \\
\hline Sir & 3 & 2 & 1 & 2 & 1 \\
\hline Cephidæ. & 1 & 1 & 1 & & $\ldots \ldots \ldots$ \\
\hline $\mathrm{X}$ & 1 & 1 & & & $\ldots \ldots \ldots$ \\
\hline $\mathrm{H}$ & 2 & 2 & 2 & .. & $\ldots \ldots \ldots$ \\
\hline $\mathrm{Pt}$ & 1 & 1 & & $\cdots$ & $\ldots \ldots \ldots$ \\
\hline Selandriidæ & 2 & 2 & & & $\ldots \ldots \ldots$ \\
\hline Nematidæ $: \ldots \ldots \ldots \ldots$ & 3 & 1 & 1 & & $\cdots \cdots \cdots$ \\
\hline Tenthredinidæ .......... & 5 & 5 & 2 & .. & $\ldots \ldots \ldots$ \\
\hline Cimbicidæ $\ldots \ldots \ldots \ldots \ldots$ & 1 & 1 & 然 & $\cdots \cdots \cdots$ & $\cdots \cdots \cdots$ \\
\hline Totals (56 families) . . . . . & 337 & 229 & 143 & 129 & 21 \\
\hline
\end{tabular}




\section{LIST OF DIPTERA.}

Attention is called to the tabulated summary which appears at the end of this list and gives a comparative disposal of the number of species with reference to families. The names of thirty-six species are reported as new to the Kansas lists. This number includes ten new species in the following families: Chironomidæ, five named and described by $\mathrm{O}$. A. Johannsen (not counting a change of name); Cecidomyiidæ, three by E. P. Felt (MS. names); Asilidæ, one by J. S. Hine; and Helomyzidæ, one by myself (description herewith incorporated): From the Colorado material, one new species in the family Trypetidæ has been described by E. T. Cresson, jr., and two new species in the family Oscinidæ are based upon my own descriptions.

Through the courtesy of Dr. L. O. Howard, chief of the Bureau of Entomology, United States Department of Agriculture, Washington, D. C.. I have been afforded the very helpful services of Mr. D. W. Coquillett in the identification of several species. Mr. E. T. Cresson, jr., has also helped me through difficulties attending the determination of species in the families Muscidæ, Borboridæ, Ortalidæ, Trypetidæ, and Ephydridæ. Other acknowledgments of assistance are made in the proper places.

The plan of systematic arrangement herein employed is the same as was used in my previous paper treating of the Diptera.

\section{Family TIPULID $Æ$.}

(Valuable aid in the identification of species in this family has been generously rendered by Mr. R. W. Doane.)

Rhipidia domestica O. S. Kansas, Lawrence; September, at night. New to the Kansas list.

Dicranomyia duplicata Doane. Colorado, Colorado Springs; August.

Dicranoptycha sobrina O. S. Kansas, Lawrence; June.

Erioptera caloptera Say. Kansas, Lawrence; May. New to the Kansas list. septemtrionalis O. S. Kansas, Lawrence; August. New to the Kansas list.

Helobia hybrida Meig. Kansas, Lawrence; October. Colorado, Denver; April, swept from grass on lawn.

Gnophomyia tristissima O. S. Kansas, Lawrence; May.

Trichocera bimacula Wk. Kansas, Lawrence; January 2, 1907, a mild (temp.

$51^{\circ}$ ), damp and cloudy day which occasioned the appearance of swarms of

these flies hovering in the air. New to the Kansas list.

Pachyrhina incurva Lw. Kansas, Lawrence; June, twilight. New to the Kansas list.

macrocera Lw. Kansas, Lawrence; May. New to the Kansas list.

polymera Lw. Kansas, Lawrence; June. New to the Kansas list. 
Tipula angustipennis Lw. Colorado, Denver; April.

bella Lw. Kansas, Lawrence; July; September. New to the Kansas list.

bicornis Lw. Kansas, Lawrence; May. New to the Kansas list. inermis Doane. Kansas, Lawrence; May, at night, and attracted by light in house; June, at night. New to the Kansas list.

Family Chironomidz.

(Prof. O. A. Johannsen has not only given great help in the specific determinations, but has named and described new species from specimens collected by me. His system of arrangement and nomenclature is followed.)

Culicoides (Ceratopogon) guttipennis Coq. Kansas, Lawrence; May. This name determined as "probably, specimen defective." New to the Kansas list.

Bezzia elegantula Joh. (Described in K. U. Sci. Bull., vol. IV, p. 109.)

Kansas, Lawrence; July, at electric light on bridge across Kansas river (type). Addition to the Kansas list.

Tanypus (Ablabesmyia) aureus Joh. (K. U. Sci. Bull., vol. IV, p. 110.) Kansas, Lawrence; July, at electric light on bridge across Kansas river (type). Addition to the Kansas list.

monilis L. Kansas, Lawrence; July, at electric light on Kansas river bridge.

Chironomus aberrans Joh. Kansas, Lawrence; July. New to the Kansas list.

flaviventris Joh. (K. U. Sci. Bull., vol. IV, p. 111.) Kansas, Lawrence; July, at electric light on bridge across Kansas river (types). Addition to the Kansas list.

halteralis Coq. Kansas, Lawrence; April, at night.

lucifer Joh. (K. U. Sci. Bull., vol. IV, p. 110.) Kansas, Lawrence; July, taken at electric light on bridge across Kansas river (types). Addition to the Kansas list.

needhamii Joh. (N. Y. State Mus. Bull., 124, p. 278). New name for species listed as C. scalænus Schrank, var., in Trans. Kan. Acad. Sci., vol. XX, pt. II, p. 197, and in K. U. Sci. Bull., vol. IV, p. 86. Being merely a change of names, no addition is made to the Kansas list. Kansas, Lawrence; June, twilight (metatype).

nigricans Joh. Colorado, Denver; August.

riparius Meig. "Defective specimen, but probably this species," according to Professor Johannsen. Colorado, Tabernash; August.

similis Joh. Professor Johannsen reported on this as "Defective specimen, may be same as similis." Colorado, Tabernash; August.

Camptocladius (Chironomus) aterrimus Meig. Kansas, Lawrence; July, twilight. New to the Kansas list.

Psectrocladius aureus Joh. (N. Y. State Mus. Bull., 124, p. 283.) Kansas, Lawrence; July (type). Addition to the Kansas list. 
Metriocnemus exagitans Joh. (K. U. Sci. Bull., vol. IV, p. 112.) Kansas,

Lawrence; March; April; April, at night (metatypes). New to the Kansas list.

Tanytarsus obediens Joh. Colorado, Colorado Springs; August.

\section{Family MYcetophiLidÆ.}

Macrocera inconcinna Lw. Colorado, Tabernash; August.

Family Cecidomyinde.

Lestremia kansensis Felt, n. sp. Kansas, Lawrence; May. Addition to the Kansas list.

leucophæa Meig. Kansas, Lawrence; August. (Det. by O. A. Johannsen.) New to the Kansas list.

vernalis Felt, n. sp. Kansas, Wichita, April. Addition to the

Kansas list.

Porricondyla tuckeri Felt, n. sp. Kansas, Lawrence; August. Addition to the Kansas list.

Family BiBionidæ.

Bibio albipennis Say. Kansas, Lawrence; May. (A single female specimen determined by W. A. Hooker.)

\section{Family THereVID E.}

Psilocephala aldrichi Coq. Colorado, Denver; August.

Family AsILId Æ.

Erax varipes Will. Colorado, Denver; August. (Det. by J. S. Hine.)

Philonicus rufipennis Hine. (Ohio Nat., vol. VII, p. 117.) Kansas, Lawrence; May and June (cotypes.) Addition to the Kansas list.

\section{Family EMPIDIDÆ.}

Tachydromia inusta Mel. Colorado, Manitou; August. The following remarks by Prof. A. L. Melander, who identified the specimens mentioned in K. U. Sci. Bull., vol. IV, p. 96, precludes any further question concerning the determination: "I have carefully compared the specimens of Tachypeza (Tachydromia) inusta with the type series. Your specimens are remarkably constant in their light color, but in the absence of any definite characters otherwise, I hardly think them to be a new species. $T$. inusta is a common species further west, and may extend into Colorado. Their cave habits may explain their lighter color."'

Rhamphomyia irregularis Lw. Kansas, Wichita; April.

masoni Coq. Kansas, Lawrence; May, at night.

\section{Family SYRPHIDÆ.}

Melanostoma mellinum L. Kansas, Lawrence; June, twilight.

Family TACHINIDÆ.

Schizotachina convecta Wk. Colorado, Colorado Springs; August.

Celatoria spinosa Coq. Colorado, Manitou; July.

Tachina rustica Fal. Colorado, Colorado Springs; August.

\section{Family SARCOPHAGIDA.}

Sarcophaga ægra Wk. Kansas, Lawrence; July. New to the Kansas list. georgina Wd. Colorado, Denver; April. Colorado Springs; August. Tabernash and Buffalo; August. 
Sorcophaga sarraceniæ Riley. Kansas, Lawrence; June; June, twilight; July; July, twilight. Wichita; August. Colorado, Denver; August.

Helicobia (Sarcophaga) helicis Towns. Kánsas, Lawrence; July, twilight. quadrisetosa Coq. Kansas, Lawrence; June; July;

July, twilight. New to the Kansas list.

Family MuscidÆ.

Cynomyia cadaverina Desv. Kansas, Lawrence; April; October. Colorado, Tabernash; August.

Calliphora coloradensis Hough. Kansas, Lawrence; April. New to the Kansas list.

Lucilia cæsar L. Kansas, Lawrence; May.

Muscina stabulans Fal. Kansas, Lawrence; May.

\section{Family ANTHOMYID}

Ophyra leucostoma Wd. Kansas, Lawrence; July, twilight; August. Colorado, Denver and Colorado Springs, August.

Homalomyia canicularis L. Kansas, Lawrence; July. New to the Kansas list. Colorado, Denver and Colorado Springs; August, numbers hovering in shade of trees.

scalaris Fab. Kansas, Lawrence; May; May, twilight; June; June, twilight; July. Wichita; April. New to the Kansas list. Colorado, Colorado Springs; August.

Hyetodesia lucorum Fal. Colorado, Tabernash; August.

Spilogaster (Hyetodesia) nigripennis Wk. Colorado, Tabernash; August. Anthomyia albicincta Fal. Colorado, Colorado Springs; July and August. radicum L. Colorado, Denver; August.

Phorbia fusciceps Zett. Colorado, Colorado Springs, Denver, and Tabernash; August.

Cœnosia flavicoxa Stein. Kansas, Lawrence; April; May; July. Wichita; April. New to the Kansas list. Colorado, Manitou; July. Colorado Springs; July and August. Denver; August. lata Wk., (=canescens Stein). Kansas, Wichita; September.

\section{Family Scatophagid Æ.}

Scatophaga furcata Say. Kansas, Lawrence; May. Colorado, Tabernash; August.

\section{Family HeLomyzide.}

Helomyza nemorum Meig. Colorado. (Det. by Aldrich and Darlington.)

Anorostoma marginata Lw. Colorado, Tabernash; August. (Det. by Aldrich and Darlington.)

Ecothea fenestralis Fal. Kansas, Lawrence; May. (Det. by Aldrich and Darlington.) New to the Kansas list.

Leria caccabata, n. sp. Kansas, Lawrence; May. Addition to the Kansas list. Type: one male specimen deposited in the United States National Museum.

General color chocolate black. Occiput and ocellar triangle black; orbital margins of front grayish; front broad, orange colored; lower portions of head brownish, except infuscated tip of proboscis. First and second antennal joints brownish; third joint infuscated, enlarged oval, with black arista as long as height of head, and minutely pubescent. 
Sparse black but rather coarse pubescence covers the occiput, front and lower half of cheeks, from which it spreads backward; second joint of antennæ scantily pubescent above and bearing a distinct bristle; ocellar bristles long, curved forward in a pair; two occipito-orbital and two marginal front bristles stout and reversely curved, arising from black dots; vibrissa single. Eyes nearly round, reddish, vertical diameter exceeding the width of cheeks by one-half the distance.

Scutellum bare, entirely grayish sericequs, bearing the usual bristles. Dorsum of thorax, the abdomen and the legs are clothed with black pubescence which is longer on the anterior femora and strongly fringes the fore and middle coxæ. A pair of grayish or inclined to brownish sericeous vittæ extends medially on dorsum, and similarly colored effects are also shown latterally under different lights. Dorsal bristles arise from black dots. Mesopleura and pteropleura wholly bare; sternopleura with four black bristles in a row close to the upper edge, the posterior bristle being twice the length of the anterior one, and the two middle ones range in length between; the median space of the sternum is covered with long black hairs.

Lateral margins of abdomen beyond first segment, and distal margins of all segments, brown, the fourth being scarcely infuscated; hypopygium full rounded, dark brownish. Coxæ, trochanters and tips of all the femora dark brownish; tibiæ and tarsi inclined to fuscous brown. Halteres brownish.

Wings hyaline, except yellowish subcostal cell, which is narrow, veins dark or fuscous brown; costal spines black, rather widely spaced; second and third veins slightly approximated, but apically divergent.

Length, $6 \mathrm{~mm}$.; wing, $5.5 \mathrm{~mm}$.

Near iners Meigen, but lacks hairs on the mesopleura, while the third antennal joint is fuscous and color of abdomen is variegated; besides, the tarsal joints of fore legs are not flattened and the spurs of the middle tibiæ are almost straight. The bristles of the sternopleura are too distinct to be classed as hairs, hence this specimen could not be placed with crassipes Loew, from which it differs in other features.

\section{Family BORBORIDÆ.}

Borborus equinus Fal. Kansas, Lawrence; June, twilight. Colorado, Tabernash; August.

geniculatus Macq. Colorado, Tabernash; August.

Sphærocera subsultans Fab. The same as cited by F. H. Snow, in K. U. Sci. Bull., vol. II, No. 5, p. 220 , as S. coprophagus, a manuscript name attributed to Dr. S. W. Williston. Kansas, Lawrence; July.

Family Sciomyzid

Sciomyza humilis Lw. Colorado, Colorado Springs; August.

obtusa Fal. Colorado, Tabernash; August.

Family SAPROMYZID $Æ$.

Sapromyza connexa Say. Colorado, Denver; August. innuba Giglio-Tos. Kansas, Lawrence; September.

Family ORTALID $Æ$.

Chrysomyza demandata Fab. Kansas, Lawrence; October. New to the Kansas list. 
Family TRYPETID $Æ$.

Tephritis genalis Thom. Colorado, Bear Creek canyon and Garden of the Gods, near Colorado City; July. Colorado Springs, August. inornata Coq. Colorado, Bear Creek canyon, near Colorado City; July.

pallidipennis Cress. (Trans. Amer. Ent. Soc., vol. XXXIII, p. 104.) Colorado, Manitou; July (cotypes).

murina Doane. Colorado, Colorado Springs; August.

Euaresta araneosa Coq. Colorado, Colorado Springs; July and August. Cheyenne canyon and Garden of the Gods, near Colorado City; July. Green Mountain Falls; July.

\section{Family EPHYDRIDF.}

Paralimna appendiculata Lw. Colorado, Colorado Springs; August. Hydrellia ischiaca Lw. Colorado, Colorado Springs; August. Philygria fuscicornis Lw. Colorado, Colorado Springs; April. Pilina truncatula Lw. Colorado, Tabernash; August.

Cænia bisetosa Coq. Colorado, Colorado Springs; August.

Family Oscinid

Chlorops graminea Coq. Colorado, Tabernash; August. (Det. by C. F. Adams.)

Ectecephala albistylum Macq. Kansas, Lawrence; June; July, twilight. (Det. by C. F. Adams.) New to the Kansas list.

Oscinis flavescens Tkr. (Ent. News, vol. XIX, p. 272.) Colorado, Manitou, 6629 feet; August, 1894 (type).

nigra Tkr. (Ent. News, vol. XIX, p. 272.) Colorado, Denver; August, 1906 (type).

variabilis Lw. Colorado, Colorado Springs; August.

Family Geomyzid $\approx$.

Scyphella flava L. Colorado, Denver; August.

Family Agromyzid $\nRightarrow$.

Agromyza æneiventris Fal. Kansas, Lawrence; August. Colorado, Colorado Springs and Denver; August. jucunda V. d. W. Colorado, Colorado Springs; August. parvicornis Lw. Kansas, Lawrence; August.

Odinia ornata Zett. (Not cited in Aldrich's catalogue.) Kansas, Lawrence;

July. New to the Kansas list.

Leucopis bella Lw. Colorado, Denver; August. 
Tabulated Summary of Families and Sipecies.

\begin{tabular}{|c|c|c|c|c|c|}
\hline Name of Family. & $\begin{array}{c}\text { Total } \\
\text { number of } \\
\text { species. }\end{array}$ & $\begin{array}{c}\text { Species } \\
\text { taken in } \\
\text { Kansas. }\end{array}$ & $\begin{array}{c}\text { Species } \\
\text { new to } \\
\text { Kansas. }\end{array}$ & $\begin{array}{l}\text { Species } \\
\text { taken in } \\
\text { Colorado. }\end{array}$ & $\begin{array}{l}\text { Species } \\
\text { taken in } \\
\text { both Kan- } \\
\text { sas and } \\
\text { Colorado. }\end{array}$ \\
\hline 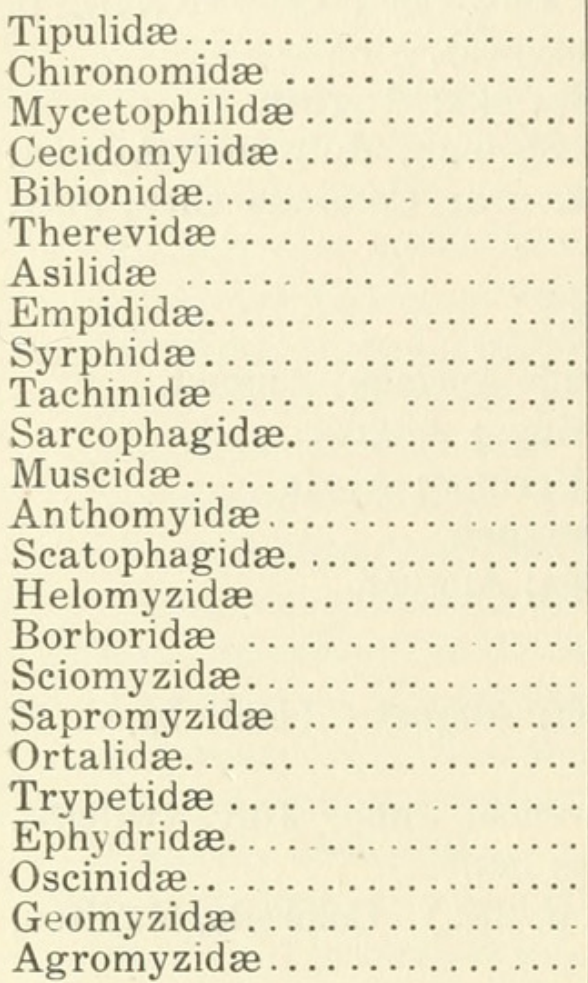 & $\begin{array}{r}15 \\
16 \\
1 \\
4 \\
1 \\
1 \\
2 \\
3 \\
1 \\
3 \\
5 \\
4 \\
10 \\
1 \\
4 \\
3 \\
2 \\
2 \\
1 \\
5 \\
5 \\
5 \\
1 \\
5\end{array}$ & $\begin{array}{c}13 \\
12 \\
\ldots \ldots \ldots \\
4 \\
1 \\
\ldots \ldots \\
1 \\
2 \\
1\end{array}$ & 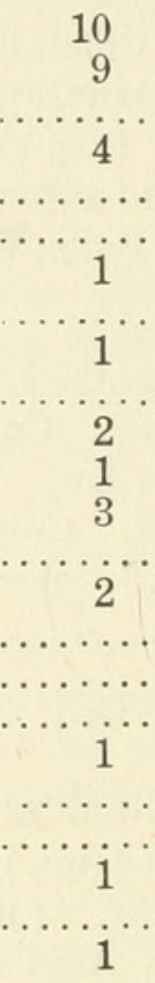 & 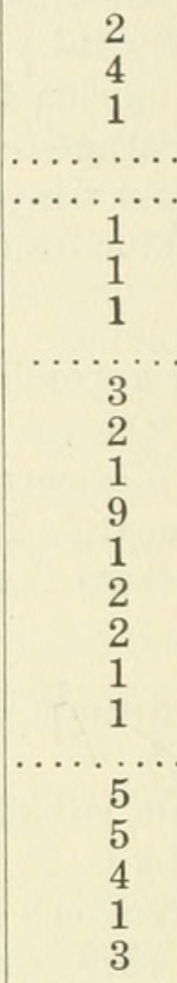 & 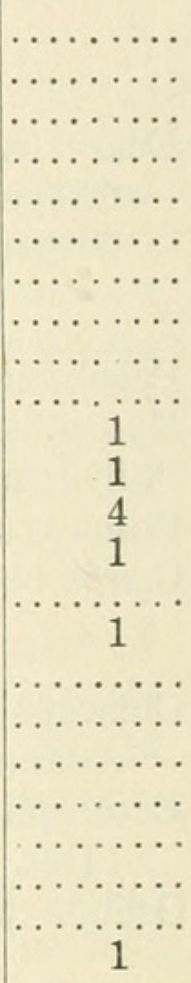 \\
\hline Totals (24 families) ...... & 100 & 58 & 36 & 50 & 9 \\
\hline
\end{tabular}

\section{LIST OF HEMIPTERA.}

Additional records are given for four species as follows, including one new addition to the Kansas list:

\section{Family CAPSID $A$.}

Agalliastes apiatus Uhl. Colorado, Buffalo; August. (Det. by O. Heidemann.)

\section{Family CORIXID}

Corixa alternata Say. Kansas, Lawrence; April, at electric light; May; May, at electric light. (Det. by O. Heidemann.) Wichita; August, at electric light.

\section{Family JASSID}

Xestocephalus fulvocapitatus V. D. Kansas, Lawrence; August. New to the Kansas list.

pulicarius V. D. Kansas, Lawrence. The record of the month of capture following the name of this species listed in K. U. Sci. Bull., vol. IV, p. 66 , should be changed from August to June. 


\section{$2 \mathrm{BHL}$ Biodiversity Heritage Library}

Tucker, Elbert Stephen. 1909. "Additional results of collecting insects in Kansas and Colorado." Transactions of the Kansas Academy of Science 22, 276-304. https://doi.org/10.2307/3624737.

View This Item Online: $\underline{\text { https://www.biodiversitylibrary.org/item/35117 }}$

DOI: https://doi.org/10.2307/3624737

Permalink: https://www.biodiversitylibrary.org/partpdf/16895

\section{Holding Institution}

Harvard University, Museum of Comparative Zoology, Ernst Mayr Library

\section{Sponsored by}

Harvard University, Museum of Comparative Zoology, Ernst Mayr Library

\section{Copyright \& Reuse}

Copyright Status: NOT_IN_COPYRIGHT

This document was created from content at the Biodiversity Heritage Library, the world's largest open access digital library for biodiversity literature and archives. Visit BHL at https://www.biodiversitylibrary.org. 